\title{
STRATEGY BMT AL-ITTIHAD USING MATRIX IE, MATRIX SWOT 8K, MATRIX SPACE AND TWOS MATRIX
}

\author{
Nofrizal, Universitas Lancang Kuning \\ nofrizalfe@unilak.ac.id \\ Prama Widayat, Universitas Lancang Kuning \\ pramawidayat@yahoo.com
}

\begin{abstract}
ABSTRAK
Penelitian ini bertujuan untuk merumuskan dan mem sh stra gi BMT A1 Ittihad Rumbai dalam menghadapi perubahan lingku ran bisı s baik dari lingkungan internal seperti sumber daya organis s, keua rar anggota dan ekternal bisnis seperti pesaing, ekonomi, p rtik. dan lan-lain. Metode penelitian ini menggunakan Analisis EF AS, AS, ratrik IE, Matrik SWOT 8K, Matrik SPACE dan M is TWO Diharapkan dengan penelitian ini dapat membantu BMT Al Ittı. d dalam memformulasi dan memilih strategi demi keberlangs agan BMT A. Ittihad di masa yang akan datang. Pengambilan sampel $d$ lam per ltian ini menggunakan teknik purposive sampling yaitu pihak, anajer dan pimpinan BMT Al Ittihad Rumbai di Pekanbaru. H sm menelmuan ini menunjukan bahwa posisi strategi BMT Al-Ittihad $2 v$ aba berada pada posisi pertumbuhan, stabilisasi dan ager t. . lapu pilihan strategi setelah mengunakan Matrik TWOS adalah $\mathrm{f}$ netra nasa, pengembangan pasar, integrasi vertikal, integrasi hori sntal, an stabilisasi (hati-hati).
\end{abstract}

Kata Kun . Yanajen. $n$ Strategi, Koperasi Syariah, Matrik TWOS.

\section{ABSTRACT}

str iegy u face the changing of business environment both from internal ivirumient such as organization resources, finance, member and - ternal business such as competitor, economy, politics and others. This research method used Analysis of EFAS, IFAS, IE Matrix, SWOT-8K Matrix, SPACE Matrix and TWOS Matrix. our hope from this research it can assist BMT Al-Ittihad in formulating and selecting strategies for the sustainability of BMT Al-Ittihad in the future. The sample in this research is using purposive sampling technique that is the manager and leader of BMT Al-Ittihad Rumbai Pekanbaru. The result of this research shows that the position of BMT Al-Ittihad using IE Matrix, SWOT-8K Matrix and SPACE Matrix is in growth position, stabilization and aggressive. The choice of strategy after using TWOS Matrix is market penetration, market development, vertical integration, horizontal integration, and stabilization (careful).

Keywords: Strategic Management, Sharia Cooperative, TWOS Matrix. 


\section{BACKGROUND}

Competition of cooperatives in the city of Pekanbaru increasingly more competitive with increase the development of an area where the cooperative was established. Pekanbaru city is a city whereas many high rise buildings have been established and will continue to grow. Pekanbaru City is also the best investment destination in Indonesia for investors of Sindo Weekly magazine (12.com, 2016). Currently the number of cooperatives active in the city of Pekanbaru amounted to 371 from the previous year only 300 with total cooperative 900 cooperatives (cooperatives and SMEs, 2014). This is certainly not separated from the role of government in the development of cooperatives in the city of Pekanbaru. Cooperatives and SMEs under the city mevernment Pekanbaru has launched several policies to make cooperative in the ity of Pekanbaru develop and advance.

Cooperatives can't separated with the community were the oo crative was built because the community that will cooperate ith ach otier to get what they want. By becoming members of the coope ative, ach $\mathrm{r}$ mber of the cooperative has different behaviors such as w? is fulfillec. and needs then members of the cooperative will feel satisfied and th sty (Arizal .N, 2016) BMT Al-Ittihad Rumbai is one of the nor oank financial institutions. Baitul Maal wa Tamwil (BMT) as a mission-driv r econor ic institution empowering small and small entrepreneurs applying shai princ ples, it has been proven to play a role in building the economy tine neopre, especially the lower layers. With the increasing economic develop ne in ekanbaru city, today we can be seen with many emerging $f^{\prime}$ anc al in titutions that apply the principles of Islamic Sharia such as Sya ah b 1ring, Sharia Pawnshops, Sharia Insurance, Sharia co-operatives an Bait Maal Wat Tamwil (BMT) in Pekanbaru city, it is causing every Shar $\leadsto$ " nancial stitution to be demanded to be more creative and innovative $b$ cause $a$ the increasingly competitive level of non-bank business to surv ve and beat the business competitors.

With th cr dition, it will arise news another non-bank financial institutior, 2 it vill $r$ anges in consumer behavior as members of BMT AlIttihad sumb i, so _.MT can't just stand alone in the position. As we know BMT A I naa ivcated close to the Chevron Fasifik Indonesia (CFI) complex of course 11 and voluntary members of BMT Al- Ittihad flat is the employee (CFI) but in 2020 the exploitation contract in 2020 will be exhausted. Based on the circumstances it takes a formulation activity and strategy implementation for BMT Al-Ittihad Rumbai which started operations on 15 June 2000 and currently has three branches in Pekanbaru City can compete and survive with increasingly competitive competition..

According to (Wheelen. Thomas L, 2016) strategic management is a series of decisions and managerial actions that determine the company's performance in the long run. These include environmental observations (external and internal), strategy formulation (long-term planning), strategy implementation, evaluation, and control. The field of strategic management science emphasizes the observation and evaluation of opportunities and threats of the environment by looking at the strengths and weaknesses of the company. 
Strategic management is in principle a decision-making that will determine whether an organization is superior, able to survive, or face death.

According Porter M (David, 2011) proposes a five-force model as a tool for analyzing an industry's competitive environment can be defined as a group of companies that produce the same product or service or close substitute. Internal factor evaluation will emphasize the identification and evaluation of strengths and weaknesses of firms in the business functional areas, including management, marketing, finance / accounting, production / operations, training and HR development, management information systems, and relationships between business areas. The strategic planner / development will be effective by using the SWOT analysis to achieve the organization's objectives (Ayub, Razzaq, Aslam, \& Iftekhar, 2013). The SWOT has four fontors namely the factors of strength, weakness, opportunities and threats nile th SWOT-8K Matrix is a development of the SWOT-4K Matrix (Muhan ad, 20,3 ).

The purpose of this Matrix IE, Matrix SPACF asage $15 \div \frac{1}{\text { ow }}$ how the position of strategy BMT Al-Ittihad Rumbi Pel nbar , the sPACE Matrix shows two internal provinces namely financirs stre ${ }^{2}$ th $\left(\mathrm{F}^{\mathrm{C}}\right)$ and competitive advantage (CA) while in external factor $d$, has $J$ provinces namely environmental stabilization (ES) and Industrial $S$. ength (IS). All these factors are critical to achieving the goals of ae company und the overall position of the company (Agus Prayitno, Suprapt Supardi 2012).

\section{RES TH IVIE THOD}

Research using qr allti ive 1 ethods, According (Sugiyono, 2012) argued that the qualitative ethe of a scribing and understanding the meaning behind the data $t^{\prime}$ at lo s. In this research to get information data we use source from tw $\mathcal{J}$ vpe the are primary and secondary data. The research method user interv. w technique, questionnaire, observation and literature study. In ais research, data analysis in the process with qualitative approach with the oll wing stages: Vision and Mission Setting, IFAS Matrix (Internal Stra $r$ tor Analysis Summary) there is evaluation of strengths and v cakne ses or 1rms in the business functional areas, including management, $\mathrm{m}_{\mathrm{k}} \mathrm{k}$ /ng, rnance / accounting, production / operations, training and HR deve nment, management information systems, and relationships between business areas. EFAS Matrix (External Strategic Factors Analysis Summary) there are two analysis the general environment and environmental industries. To determine the strategic position using IE Matrix (Mirzakhani, Parsaamal, \& Golzar, 2014), SWOT-8K Matrix (Nofrizal, 2016) and SPACE Matrix (Nurlaelasari, et all, 2014). As for the selection strategy using TWOS Matrix (Hashemi, et all, 2012).

\section{RESULTS AND DISCUSSION}

BMT Al-Ittihad Rumbai is the business development of the Islamic Education Unity Foundation (YKPI) Rumbai, by implementing the principle of Cooperation in accordance with Act No. 25 of 1992 on Cooperatives, but using the principle of Sharia Cooperative, started operations since June 15, 2000 with 
the name Baitul Maal Wat Tamwil Al-Ittihad, incorporated as of 31 January 2001 Number. 272 / BH / DISKOP \& UKM / 3 / X / 2001, Letter of Business License (SITU) number 517 / H / UPT / WK-2003, and BMT Optional Certificate number 034 / PINBUK / Riau / XI / 2000, addressed Cemara No. complex. 418, Camp PT. CPI, Rumbai Pekanbaru.

The vision carried by BMT Al-Ittihad is "Become an integrated Islamic da'wah center to create a civil society that is prosperous born and inner and happy world and hereafter".

Mission "To encourage the creation of people in the field of Islamic muamalat business development”.

After we look and analysis vision and mission BMT Al-Ittihad Rumbai we sure that vision and mission was suitable with core $b$ siness management to capture opportunity in Pekanbaru City. Next a alyzing ising general environmental analysis and industrial enviror nent $\mathrm{cl}^{\text {sis' }} \mathrm{ng}$ of economic, social, politics, environment, technology, - $\mathrm{mp} f$ tor, nuwcomer, buyer, supplier, product of substitute hence EF $\Lambda S$ a tlysis of external environment BMT Al-Ittihad Rumbai found as in a 1 belo We found that BMT Al-Ittihad in good condition with positive value.

Table 1. EFAS (External Environment) BN T Al-Itti ad Rumbai

\begin{tabular}{|c|c|c|c|}
\hline Opportunity & Weight & Scale & Score \\
\hline $\begin{array}{l}\text { Implementation of laws on cooperati to som cencind } \\
\text { and local government }\end{array}$ & 0.02 & 4 & 0.08 \\
\hline $\begin{array}{l}\text { Government programs and vance cooperative } \\
\text { progress }\end{array}$ & 0.02 & 4 & 0.08 \\
\hline $\begin{array}{l}\text { Public economic condil } \mathrm{ns} \text { as (Revenue, } \\
\text { Expenditure) }\end{array}$ & 0.12 & 4 & 0.48 \\
\hline The state of Chevron' andition 1 the future & 0.07 & 4 & 0.28 \\
\hline The opening of briuge tra nortation access & 0.05 & 3 & 0.15 \\
\hline $\begin{array}{l}\text { The proliferati } \text { of continu } s \text { increases in the price of } \\
\left.\text { goods (infla }{ }^{+}{ }_{J}\right)\end{array}$ & 0.09 & 4 & 0.36 \\
\hline Slow market ro a & 0.05 & 4 & 0.20 \\
\hline $\begin{array}{l}\text { The ny }{ }^{r} \text { ol eople esiding around BMT Al-Ittihad } \\
\text { is a otenti mark share }\end{array}$ & 0.21 & 4 & 0.84 \\
\hline $\mathrm{Po}_{\mathrm{H}}$ latir BMT Al-Ittihad Rumbai is Islamic & 0.09 & 4 & 0.36 \\
\hline $\begin{array}{l}\text { are very nid in an effort to improve business efficiency } \\
\text { in the environment BMT Al-Ittihad and society }\end{array}$ & 0.12 & 4 & 0.48 \\
\hline Threat & Weight & Scale & Score \\
\hline $\begin{array}{l}\text { The amount of high competition between similar } \\
\text { financial institutions and other conventional financial } \\
\text { institutions }\end{array}$ & 0.03 & 4 & 0.12 \\
\hline Easier institutions / individuals to open cooperatives & 0.04 & 3 & 0.12 \\
\hline $\begin{array}{l}\text { There are many replacement products that people can } \\
\text { choose when they want to use cooperative services }\end{array}$ & 0.05 & 4 & 0.20 \\
\hline $\begin{array}{l}\text { The buyer's bargaining power has a major influence on } \\
\text { the operation of BMT Al-Ittihad Rumbai }\end{array}$ & 0.01 & 4 & 0.04 \\
\hline $\begin{array}{l}\text { There are many suppliers to support / support the } \\
\text { business operations of BMT Al-Ittihad }\end{array}$ & 0.03 & 4 & 0.12 \\
\hline Total & 1 & & 3.91 \\
\hline
\end{tabular}


Based on table 1 above about the analysis of the external environment BMT Al-Ittihad Rumbai city Pekanbaru we know that BMT Al-Ittihad condition was positioned positively with the value 3.91 , then from the value of opportunities found the factors of technological progress and economic circumstances that the community's income in good condition with score 0.48 , this shows that BMT Al-Ittihad Rumbai has a great opportunity to capture the cooperative market opportunities in Pekanbaru City with this condition is also of course BMT Al-Ittihad to advance and grow also larger.

While on the threat factor is known value that has a big influence on the future of BMT Al-Ittihad Rumbai is the amount of high competition between similar financial institutions, Easy to open cooperatives and there are many products replacement, with this condition BMT Al-Ittihad will not be easy to go forward and compete, but this threat can be over by 1 arnessi. o the power still held to be discussed in the IFAS 2 next table.

Table 2.IFAS (Internal Environment) BMT Al-Itt ad P .mbai

\begin{tabular}{|c|c|c|c|}
\hline Strength & W ght & Scale & Score \\
\hline Qualified human resources & 0.05 & 4 & 0.20 \\
\hline $\begin{array}{l}\text { There are skills development and motivation progra } \\
\text { employees }\end{array}$ & 0.01 & 3 & 0.03 \\
\hline Have career development programs for er ployees & 0.11 & 3 & 0.33 \\
\hline $\begin{array}{l}\text { Having SOP (Standard Operating Proced e) in runr ig the } \\
\text { business }\end{array}$ & 0.07 & 3 & 0.21 \\
\hline $\begin{array}{l}\text { There are rewards and punishmen outstaiın. employees } \\
\text { and mistakes }\end{array}$ & 0.05 & 3 & 0.15 \\
\hline The current financial condi ${ }^{-}$of $\mathrm{B} "$ Al-Ittihad & 0.08 & 3 & 0.24 \\
\hline Amount of Debt with ar ity to epay ebt & 0.05 & 3 & 0.15 \\
\hline $\begin{array}{l}\text { Have other business } u_{1} \text { s to } \\
\text { other than cooper? ves }\end{array}$ & 0.09 & 1 & 0.09 \\
\hline Have innovativ oducts on red to the public / customers & 0.09 & 3 & 0.27 \\
\hline Has a wide market $\mathrm{s}$ rentation for BMT Al-Ittihad products & 0.08 & 4 & 0.32 \\
\hline $\begin{array}{l}\text { It has fac' }{ }^{\prime} \text { les and sev } \text { al branches for easy reach by the } \\
\text { comm' Aty / } c \text { stomers }\end{array}$ & 0.03 & 3 & 0.09 \\
\hline BMT \& Itt ad already known by the public & 0.04 & 3 & 0.12 \\
\hline $\mathrm{F} \triangle \mathrm{f}$ re irem $\Delta \mathrm{t}$ to become a new member & 0.05 & 4 & 0.20 \\
\hline eakn is $>$ & Weight & Scale & Score \\
\hline $\mathrm{Th}$ apabilities of BMT Al-Ittihad Rumbai employees & 0.01 & 3 & 0.03 \\
\hline $\begin{array}{l}\text { e state of communication between employees and between } \\
\text { leat } \mathrm{s} \text { and employees }\end{array}$ & 0.03 & 3 & 0.09 \\
\hline Employee wellbeing so far & 0.05 & 3 & 0.15 \\
\hline Relationship between management and employees & 0.03 & 3 & 0.09 \\
\hline $\begin{array}{l}\text { Implementation of SOP (Standard Operating Procedure) which } \\
\text { has been made by the management }\end{array}$ & 0.03 & 3 & 0.09 \\
\hline The physical condition (Building) BMT Al-Ittihad & 0.02 & 3 & 0.06 \\
\hline Not so much promoting new customers & 0.01 & 3 & 0.03 \\
\hline effective promotion through advertisements and newspapers & 0.01 & 3 & 0.03 \\
\hline Have a programmed and programmed marketing strategy & 0.01 & 3 & 0.03 \\
\hline Total & 1 & & 3.00 \\
\hline
\end{tabular}

Based on table 2 above obtained internal calculation results BMT AlIttihad Rumbai show the same positive with the results obtained in the previous 
EFAS table. From the power factor, it know that the strongest strength factor is to have a career development program for employees, BMT Al-Ittihad's current financial condition and has wide market segmentation for BMT Al-Ittihad products. While on the weakness factor there are some that have a big effect on BMT Al-Ittihad is the welfare of employees over the years and Implementation of SOP (Standard Operational Procedures) that have been made by the management. Based on these factors then the total score score of BMT AlIttihad Rumbai is 3.00 this means the condition of BMT at this time remain in good condition but must keep improving on the weakness. In addition, some of the weaknesses of the piles of many human resource problems (HR). Therefore, this problem can be solved in many ways such as training, reward and punishment or can also improve the system of recruitment of amnloyee to get reliable man power.

From the calculation table IFAS and EFAS obtained EFA value o 3.91 and score for IFAS results of 3.00. When converted nto the IE Matrix Diagram, then it is located in boxes 1 and 5, where the sulto of the urm enter into the Growth and Stability phases see figur 1 belo.

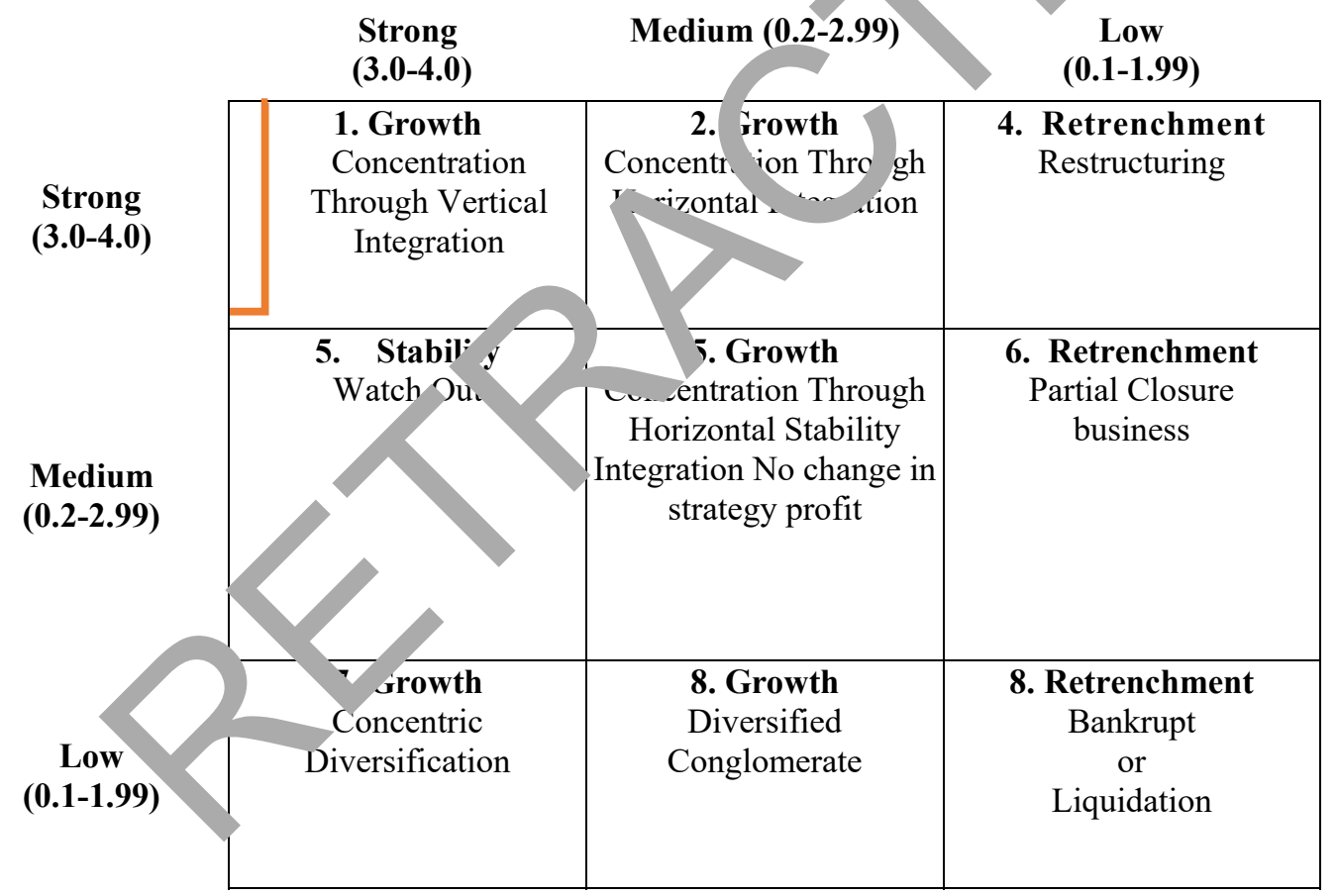

Figure 1. Matrix IE BMT Al-Ittihad Rumbai

Based on the IE Matrix image above the strategy that can be used is growth (growth) through vertical integration of construction this means BMT Al-Ittihad can use growth strategy Integration strategy is a strategy to seek ownership or improve control of company suppliers. The strategy is particularly appropriate when the company's suppliers are not reliable, overpriced, or do not meet the needs of the company or seek ownership of the distribution of products to customers by acquiring product distribution.

Besides using IE Matrix, this research also uses SWOT 8K Matrix. This matrix has eight (sub) quadrants. The SWOT-8K matrix is useful for 
formulating corporate planning because this matrix will show what strategy is appropriate to use. This matrix is derived from the difference between EFAS and IFAS values. The result of calculating the value of the difference of opportunity and the threat from external factor is the value of 2.71. While the difference between strength and weakness of internal factors with value 1.80. Based on these results it can be concluded that the position of BMT strategy Al-Ittihad Rumbai is in the Stable Growth Strategy (stable Growth Strategy) or in the quadrant IA as in Figure 2 below

\section{Opportunities}

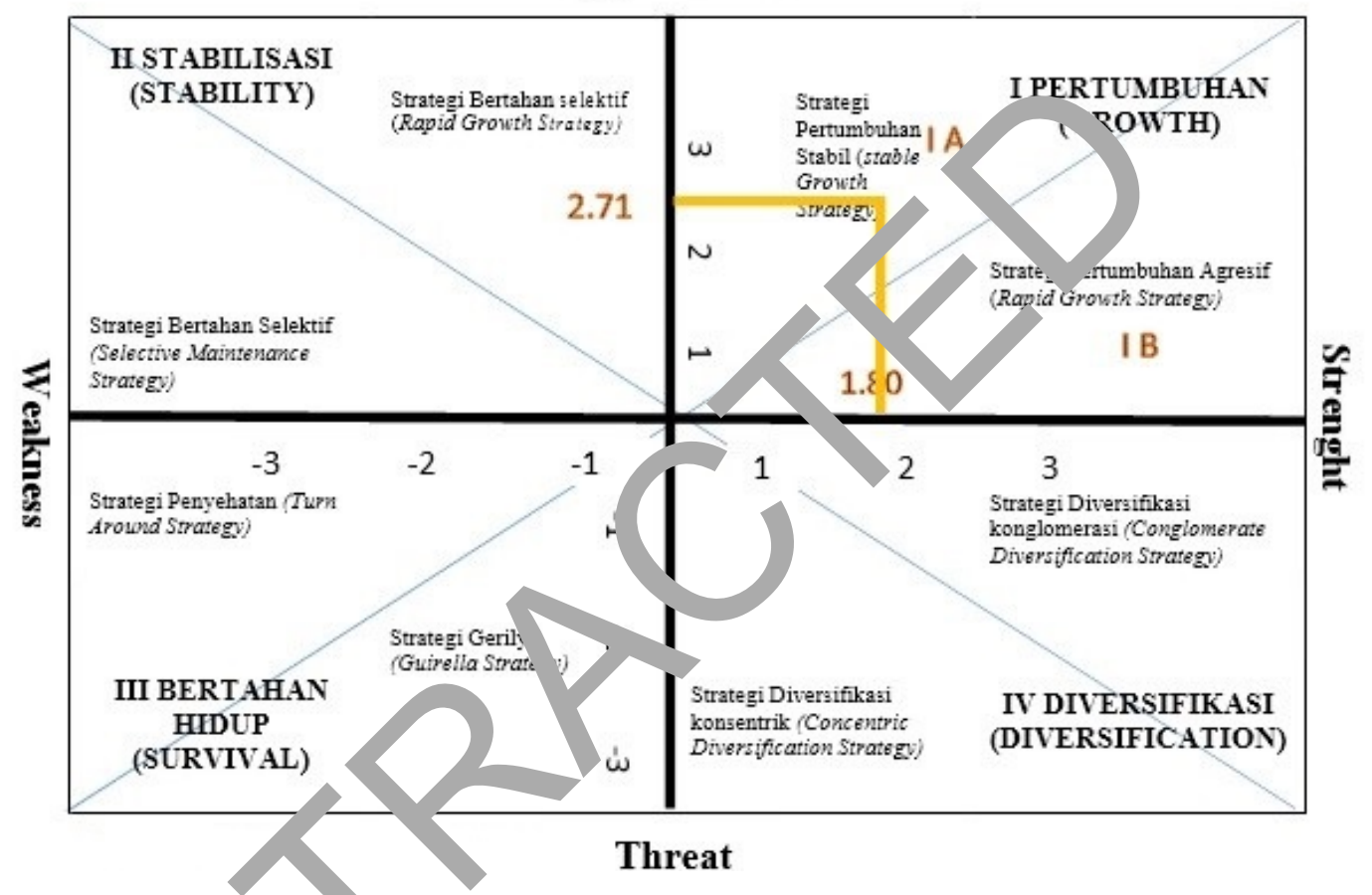

Figure 2. Matrix SWOT 8K BMT Al-Ittihad Rumbai

Rase on th above picture 2 it can be retrieved that the right strategy th $a$ car be do by BMT Al-Ittihad is a Growth Stable Strategy (stable Growth $S$ ate $3 y$, is strategy means that this strategy is usually done by companies that have many power items, while they are in an industry with high attract eness. Simply put, the company is having the strength or ability to expand, because of its attractive external conditions, and favorable internal conditions. Ability here could be in the form of financial resources (can be own funds or funds from third parties), or resources of any kind. As a business organization, instinct to always grow is always there. There are two strategies for growth that is (concentration) and Diversification (diversification).

Next use the SPACE Matrix consisting of a four-quadrant framework consisting of aggressive, conservative, defensive, and comprehensive strategies, in which these four quadrants indicate which strategy best fits a particular organization. The SPACE Matrix Axis depicts two internal dimensions and two external dimensions. Two internal dimensions include strength (financial strength $=$ FS) and competitive advantage (CA).

Results after using the SPACE Matrix by observing the four demands and 
distributing questionnaires to BMT Al-Ittihad it was found that the position of BMT Al-Ittihad Rumbai was in the Aggressive position with the total value of horizontal axis 1.75 while the vertical axis 1.70 .

Table 3. Matrix Space BMT Al-Ittihad Rumbai

\begin{tabular}{|c|c|c|c|}
\hline Financial Strength (FS) & Rating & $\begin{array}{c}\text { Environmental Stability } \\
\text { (ES) }\end{array}$ & Rating \\
\hline a. ROI & 3 & a. Technology changes & -3 \\
\hline b. Leverage & 3 & b. Competition Pressure & -2 \\
\hline c. Liquidity & 4 & c. Demand Diversity & -1 \\
\hline \multirow[t]{2}{*}{ d. Working capital } & 4 & d. Price competition & -1 \\
\hline & & e. Inflation Rate & -2 \\
\hline $14 / 4$ & 3.50 & & -1.8 \\
\hline Competitive Advantages (CA) & Rating & Industrial Strength & ating \\
\hline a. Market share & -1 & a. Growth Potential & 3 \\
\hline b.Quality Products and awards & -2 & b. Resource Utiliz ion & 3 \\
\hline c. Customer loyalty & -1 & c. Ease of Entr anto In ast & 3 \\
\hline d. Knowledge of technology & -2 & d. Productivity & 4 \\
\hline 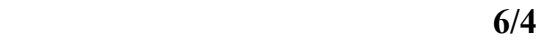 & -1.5 & & 3.25 \\
\hline & & & 1.75 \\
\hline & & & 1.70 \\
\hline
\end{tabular}

Based on the above table it is known that tr state of BMT Al-Ittihad Rumbai in the state of aggressive str to o. see ngure 3 below, the strategy has meaning means the company is in a go dostwon to use its internal strength to take advantage of external o por initi s, overcome internal weaknesses, and avoid external threats. Thu mar' $^{1}$ s nen tration, market development, product development, backward iteg, ion, forward integration, horizontal integration and conglomerate $A$ rsifica n (concentric diversification, horizontal diversification car be on effective strategy that can be used by BMT AlIttihad Rumbai

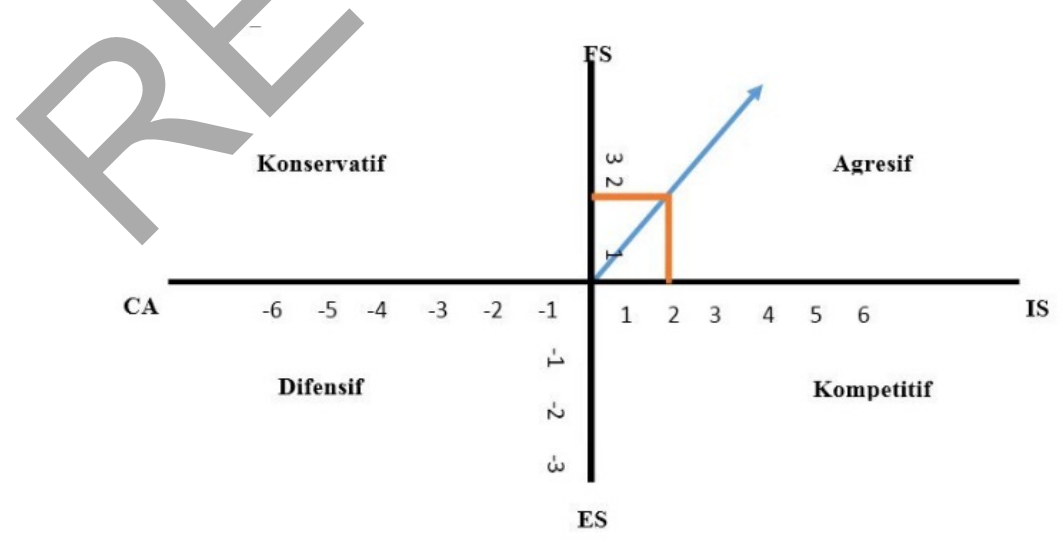

Figure 3. Matrix SPACE BMT Al-Ittihad Rumbai

The last stage in BMT Al-Ittihad Rumbai strategy development is the selection of strategy using TWOS matrix see table 6 after considering EFAS Matrix, IFAS Matrix, IE Matrix, SWOT 8K Matrix and SPACE Matrix. Based 
on the TOWS Matrix then BMT Al-Ittihad Rumbai can choose and use some formulation of strategy to run the cooperative in the future that is as follows:

1. Maximize the 4 branches that are owned now by providing maximum service to customers.

2. Creating attractive programs to new and old prospective customers such as products for children's education, umrah and haji

3. Maximize the program for human resource development to improve HR performance.

4. Create a growth strategy by opening a business unit that is related to a business unit or unrelated to a business unit

5. Partnering with SMEs and SMEs in the city of Pekanbaru.

6. Create a interesting campaign to prospective new curtamers and old customers by way of computing between the cooper ave in 'ustry in the city of Pekanbaru such as promotion of interest credit nd ease f lending.

7. Provide an understanding to the employee that ar coop rat $e$ is the best cooperative in Pekanbaru city with a series of war'

BMT Al-Ittihad Rumbai is a business $n$ that mo s to save and borrow with the concept of cooperative sharia. With the a vancement of the region and the increasing number of people incre ising the day it becomes an opportunity for entrepreneurs or investors as wel as to ce ture economic opportunities to generate profits. Cooperatives as a neans of financing that have mutual cooperation attitude also appe $r$ luding BMT Al-Ittihad as a cooperative sharia. With the increasing nu $b^{r}$ or emerging cooperatives and financial institutions, competitio is nev able for it needed a strategy in order to compete and survive? the twre

The result $s$ this search shows that BMT Al-Ittihad fringe is in good position this is a cated $\mathrm{b}, 3$ matrix that is IE matrix, SWOT $8 \mathrm{~K}$ matrix and SPACE Mat ix like « ble 5 below.

Table 5. $२ \mathrm{M}$ Al-Ittihad strategic position using IE Matrix, SWOT 8K Matrix, SPA Ma ix

\begin{tabular}{ccc} 
& Matrix SWOT 8K & Matrix SPACE \\
\hline Gro th Strategy Vertical & Growth \& Stable & Aggressive Strategy \\
Concentration & Strategy (stable Growth & \\
& Strategy &
\end{tabular}

Based on the picture above can be concluded that BMT Al-Ittihad Rumbai strategy is in a healthy position. Under these circumstances, BMT AlIttihad can do many things for future strategies such as market penetration, market development, product development, backward integration, forward integration (a strategy implemented by gaining control over the distribution channels, from distributors to retailers), horizontal integration and diversification of conglomerates. 


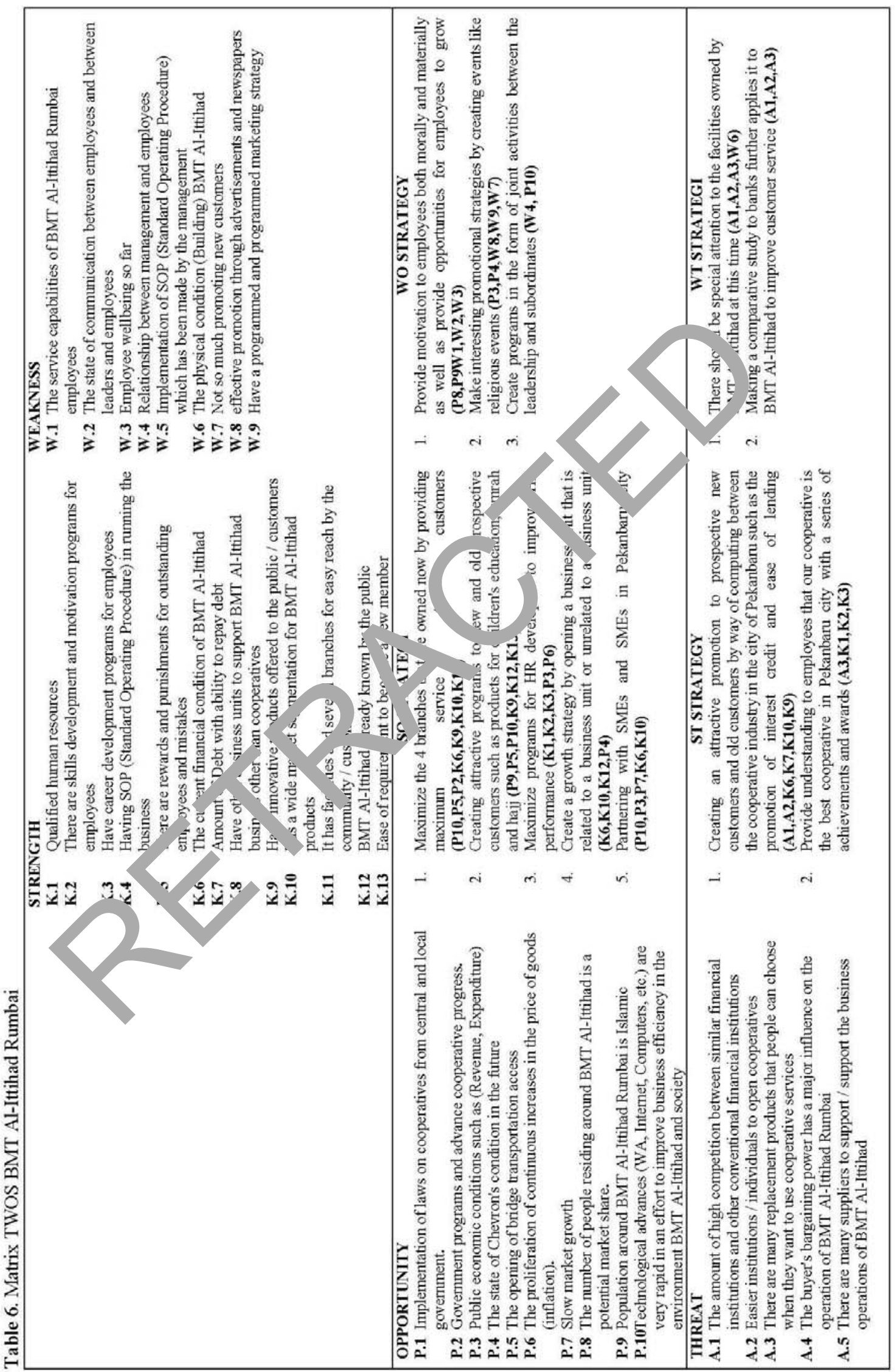


The above strategies can be formulated into the TWOS matrix including maximizing the 4 branches that are owned now by providing maximum service to the customer in accordance with the opinion of (Firdaus, 2011)with the title of research to build and implement balanced scorecard on public sector, attractive programs to new and old prospective customers such as products for children's education, umrah and hajj and maximizing program for human resource developers to improve HR performance.

As for the reason why BMT Al-Ittihad Rumbai should focus on maximizing 4 branches and improving the ability of employees this is in accordance with the revelation (Supriyadi, 2017) that the results show that the motivation and managerial effect on employee performonce because of financial ability is quite good plus the number of customer the ma $y$ as well as the esteem-pricing from the government or institution hat can be a good image. The best way to convey this is to use mark tin strategy in accordance with the opinion (Saputro, A. S., Hic vat. .., \& M ulianto, 2016) that the results of the research show the appror ate ategy ior PT. Telkomsel Branch Malang is an intensive strategy $o$, risting $r$ market penetration, market development, and product develonment.

\section{CONC USIOI}

From the result of this re an $^{\text {h }}$ it can be concluded that BMT Al-Ittihad as sharia cooperative has strateg. fr muration BMT Al-Ittihad Rumbai can use growth strategy, aggres ive nd ability while position of BMT strategy AlIttihad Rumbai is in rood ncitio. because it is in positive quadrant that is aggressive, grow a, an stabilization while from the three matrix IE matrix matrix SWOT \& nd mat SPACE matrix all show good performance which is suggested to use $\mathrm{g}$ wth strategy and stabilization after known from TWOS matrix an iysis to formulate strategy found some strategy that can be selected BMT A. Itt' ad among them maximize 4 branches that already exist that is brar .... s. h mb? oranches. Panam and branches. Duri, open cooperation with S JEs nd SN Es, maximize the performance of the customers by creating pi ams opening business units, conducting programs or promotional proa ts related to Islamic religious values.

While the advice of BMT Al-Ittihad Rumbai is BMT Al-Ittihad Rumbai should be able to analyze the external and internal environment because this environment is very fast changing and sometimes not terpredeksi by the management then create a list of especially list for top leaders and managers, BMT Al-Ittihad maximizing the advantages possessed now as a positive image both government and private and customers, BMT Al-Ittihad can use social media as a product promotion tool to potential customers or existing customers, BMT Al-Ittihad can use existing finance by making diversified products to society in accordance with the needs of today's society and religious programs quite often done in the city of Pekanbaru is a good opportunity for BMT AlIttihad to serve as a sponsor to introduce products BMT to the city of Pekanbaru. 


\section{REFERENCES}

12.com, R. 2016. Pekanbaru Tujuan Investasi Terbaik di Indonesia. Retrieved from http://www.riau12.com/read-501-3921-2016-03-14-pekanbarutujuan-investasi-terbaik-di-indonesia.html

Agus Prayitno, Suprapti Supardi, E. D. N. 2012. Analisis Strategi Pengembangan Agribisnis Komoditas Sayuran Unggulan Di Asosiasi Aspakusa Makmur Kabupaten Boyolali. MEDIAGRO, 8(2), 8-20.

Arizal .N, N. 2016. Pengaruh Bauran Pemasaran Jasa Terhadap Kepuasan Anggota Pada Koperasi Syariah (Studi Kasus Pada $\mathrm{Bm}^{+}$4l-Ittihad Pekanbaru). Daya Saing, 4(4), 192-199.

Ayub, A., Razzaq, A., Aslam, M. S., \& Iftekhar, H. J13. A Cor eptual Framework on Evaluating SWOT Analysis as th Med ator in Strategic Marketing Planning through Marketing Inte ${ }^{1}$ genc Busi ess and ..., 2(1), 91-98. F 5 from http://www.ejbss.com/Data/Sites/1/vol2nolaprila 13/ejbss-vol-2-no1_april2013.pdf\#page $=150$

David, F. R. 2011. Strategic Manageme, Mar jemen Strategis Konsep. Jakarta: Pearson education, Sal niv Empal.

Firdaus, D. W. 2011. Memb? gu dan mplementasi balanced scorecard pada sektor publik. Jurnal. sidar Llknnmi. Majalah Unikom, 9(1).

Hashemi, N. F., M.九 sh, M. M., Razeghi, A., \& Rahimian, A. 2012. Formulating And $\mathrm{Ch}_{\mathrm{H}}$ asing Strategies Using SWOT Analysis and QSPM Matrix: Case Stuay Of Hamadan Glass Company. International Conferer, ec . Computers \& Industrial Engineering, 3(4), 366-371.

Mirzak ani, I., Paı aamal, E., \& Golzar, A. 2014. Strategy Formulation with S C , Matnx: A Case Study of an Iranian Company. Global Business \& Man rement Research, 6(2), 150-168. Retrieved from http://www.systems.wsu.edu/scripts/wsuall.pl?url=http://search.ebscohos t.com/login.aspx?direct $=$ true $\& d b=$ th $\& A N=98850616 \&$ site $=$ bsi-live

Muhammad, S. 2013. Manajemen Strategik Konsep dan Alat Analisis. Yogyakarta: UPP STIM YKPN.

Nofrizal, N. 2016. Strategi Tumbuh Dan Bersaing Di Industri Asuransi (Studi Kasus Pada BPJS Ketenagakerjaan Pekanbaru). Pekbis Jurnal, 8(3), 228240.

Nurlaelasari, R., Yopita, M., \& Durahman, A. 2014. Corporate Strategic Management Analysis of PT Ultrajaya Milk Industry and Trading 
Company Tbk. International Journal of Science and Research (IJSR), 3(6), 2178-2183.

Saputro, A. S., Hidayat, K., \& Yulianto, E. 2016. Perencanaan Strategi Pemasaran Paket Data Kampus Dalam Persaingan Di Bidang Paket Data Internet (Studi Kasus Pada Pt. Telkomsel Cabang Malang). Jurnal Administrasi Bisnis, 36(1), 163-169.

Sugiyono, P. 2012. Metode Penelitian Kuantitatif, Kualitatif dan R\&D. Bandung: Alfabeta.

Supriyadi, D. 2017. Pengaruh Motivasi Dan Manajerial T^rhadap Kinerja Karyawan Bank. Value: Journal of Management and Busint. 1(2).

Wheelen. Thomas L, H. J. D. 2016. Strategic Manas ment $a_{t}{ }^{\prime} B$, iness Policy TOWARD GLOBAL SUSTAINABILITY. (13; Edi+ on, Ed.). Pearson. 


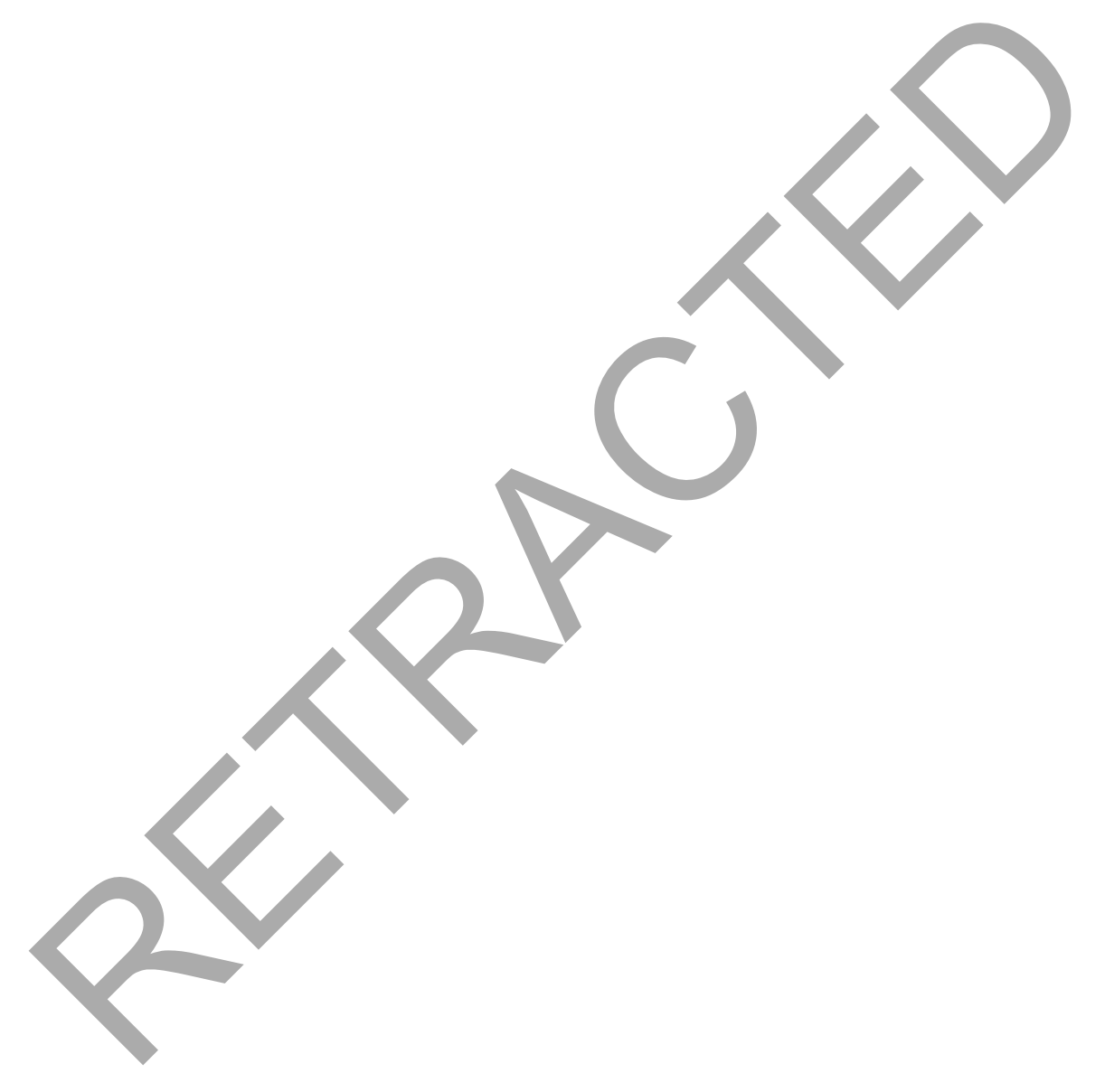

